\title{
Effect of Different Doses of NK Chemical Fertilizers and Compost on Growth and Yield Attributes of Tomato (Lycopersicon esculentum Mill.)
}

\author{
Thayamini Harold Seran*, Mohamed Saleem Mohamed Imthiyas
}

Department of Crop Science, Faculty of Agriculture, Eastern University, Chenkalady, Sri Lanka A R T I C L E I N F O

Article history:

Received 06 December 2015

Accepted 03 May 2016

Available online, ISSN: 2148-127X

Keywords:

Compost

Fruit yield

Pulp consistency

Tomato

Total soluble solid

${ }^{*}$ Corresponding Author:

E-mail: thayaminis@esn.ac.lk

\section{A B S T R A C T}

This study was conducted to evaluate the effect of NK chemical fertilizers in combination with compost on the growth and yield attributes of tomato (Lycopersicon esculentum Mill.). The pot experiment was done in a complete randomized block design possessing eight treatments with four replicates. Fruit weight, pulp weight, seed weight, total soluble solid, leaf area and dry weights of plat parts were taken and fruit yield was calculated. All the collected data were subjected to statistical analysis. The results revealed that there were significant differences in fruit and seed weights, total soluble solid, pulp weight, 100 seed weight, pulp consistency, leaf area and crop residue. In these parameters, higher mean values were recorded in chemical fertilizers $\left(7.5 \mathrm{~g} \mathrm{~N}+6 \mathrm{~g} \mathrm{~K}_{2} \mathrm{O}+15 \mathrm{~g} \mathrm{P}_{2} \mathrm{O}_{5}\right.$ per m$\left.{ }^{2}\right)$ with compost $\left(2 \mathrm{~kg}\right.$ per $\left.\mathrm{m}^{2}\right)$ than those in the chemical fertilizers applied alone $(9.0 \mathrm{~g} \mathrm{~N}+$ $8 \mathrm{~g} \mathrm{~K}_{2} \mathrm{O}+15 \mathrm{~g} \mathrm{P}_{2} \mathrm{O}_{5}$ per $\mathrm{m}^{2}$ as standard control). Total soluble solid and fruit yield were $5.73^{\circ}$ brix and $3.21 \mathrm{~kg} / \mathrm{m}^{2}$ respectively in the chemical fertilizers with compost $(7.5 \mathrm{~g} \mathrm{~N}+$ $6 \mathrm{~g} \mathrm{~K}_{2} \mathrm{O}+15 \mathrm{~g} \mathrm{P}_{2} \mathrm{O}_{5}+2 \mathrm{~kg}$ compost per $\mathrm{m}^{2}$ ) treated plants and these were statically on par with the standard control which gave $4.36^{\circ}$ brix total soluble solid and $3.05 \mathrm{~kg} / \mathrm{m}^{2}$ fruit yield. The result could be concluded that application of chemical fertilizers $(7.5 \mathrm{~g} \mathrm{~N}$ $+6 \mathrm{~g} \mathrm{~K}_{2} \mathrm{O}+15 \mathrm{~g} \mathrm{P}_{2} \mathrm{O}_{5}$ per $\left.\mathrm{m}^{2}\right)$ with compost $\left(2 \mathrm{~kg}\right.$ per $\left.\mathrm{m}^{2}\right)$ could increase the total soluble solid and fruit yield as well as reduce the usage of chemical fertilizers in tomato cultivation over the standard control in sandy regosol.

\section{Introduction}

Tomato (Lycopersicon esculentum Mill.) is one of the vegetable crops and highly grown throughout the world. It is a significant cash crop for commercial farmers in Sri Lanka and a vital source of vitamin. Tomato crops are cultivated throughout the year to increase farmer's income however, adequate amount of quality seeds are required to achieve vigorous vegetative and reproductive growth for obtaining high quantities of fruit and seed yield. Generally farmers intend to increase crop production with extreme use of macronutrients however micronutrient supply is required to enhance the plant activities for increasing crop production. Therefore, application of fertilizers containing macro and micro nutrients is needed in tomato cultivation.

Kumar (2003) reported that application of $25 \mathrm{t} / \mathrm{ha}$ farm yard manure $(\mathrm{FYM})+150 \%$ NPK $(150: 112: 82.5 \mathrm{~kg} / \mathrm{ha}$ NPK) in tomato is the best for obtaining high growth, yield and quality of tomato. Excess and continuous use of chemical fertilizers in vegetable cultivation can lead to deteriorate the soil and nearby waterways (Aisha et al., 2007). Further, it may result in excess vegetative crop growth. To overcome these problems, the use of compost results in higher crop quality performances (Mehdizadeh et al., 2013) and it contains macronutrients, essential micronutrients and beneficial microorganisms (Natarjan, 2007; Sreenivasa et al, 2010). Incorporation of organic manure to soil boosts microbial activities towards increasing soil fertility and fertilizer use efficiency (Nanwai et al., 1998), increases the crop physiological function (Awad et al., 2002) and provides better performance in different stages of crop production. In viewing this concept, this study was aimed to evaluate the effect of NK chemical fertilizers and compost on the growth and yield performance of tomato in sandy regosol.

\section{Materials and Methods}

In order to assess the effect of NK fertilizers and compost on the growth and yield attributes of tomato, an experiment was carried out at the Crop farm, Eastern University of Sri Lanka in 2013 and 2014. The experiment site is situated in the Eastern region of Sri Lanka where the annual rainfall ranges between 1600 to $2000 \mathrm{~mm}$, annual mean temperature is from $28^{\circ} \mathrm{C}$ and $32^{\circ} \mathrm{C}$ and relative humidity ranges from $50 \%$ to $75 \%$. The type of soil is sandy regosol. Soil and compost analysis were done on dry basis except $\mathrm{pH}$ and Electric conductivity. Kjeldahl and UV visible Spectrophotometer were used to determine quantities of Nitrogen and $\mathrm{P}_{2} \mathrm{O}_{5}$ respectively. Atomic absorption spectrometry was used to analyze $\mathrm{K}_{2} \mathrm{O}, \mathrm{Ca}, \mathrm{Mg}, \mathrm{Cu} \mathrm{Fe}, \mathrm{Mn}$ and $\mathrm{Zn}$ using $\mathrm{HNO}_{3}: \mathrm{H}_{2} \mathrm{SO}_{4}: \mathrm{HClO}_{4}(9: 4: 1)$ acid digestion. The chemical properties of soil and compost were given in Table 1. 
Compost was made by incorporating cowdung: goatdung: paddy straw: gliricidia green leaves at equal weight basis.

The pot experiments were done in a complete randomized block design with eight treatments (Table 2) and three replications. Size of the polybags was $45 \mathrm{~cm}$ length and $30 \mathrm{~cm}$ diameter. Seeds of tomato cv KWR are sown in a nursery and four weeks old healthy seedlings were transplanted in the polybags which were arranged at a spacing of $80 \mathrm{~cm}$ between two rows and $50 \mathrm{~cm}$ within them. Two seedlings were placed at each polybag. Different levels of nitrogen and potassium from chemical fertilizers (urea and muriate of potash respectively) and compost were applied as a basal dressing prior to planting followed by topdressings of nitrogen fertilizer at $3^{\text {rd }}$ week and $6^{\text {th }}$ week after planting but potassium fertilizer at $6^{\text {th }}$ week as described in Table 2. Compost was incorporated to the soil during the preparation of polybags. Basal application of phosphorus $\left(\mathrm{P}_{2} \mathrm{O}_{5}\right)$ at a rate of $15 \mathrm{~g} / \mathrm{m}^{2}$ from triple superphosphate was applied to all plants except in treatment T1. Agronomic practices except nutrient management were followed according to the recommendation of the Department of Agriculture of Sri Lanka.

At weekly interval, fruits were harvested from $9^{\text {th }}$ week onwards after transplanting it was continued till crop reached peak production which was four picks. Fruit weight, seed weight, leaf area, total soluble solid and other important growth and yield parameters were recorded meanwhile all the dry weights except fruit related dry weights were air dried for five days. Fruit and pulp were placed in an oven at a temperature of $70^{\circ} \mathrm{C}$ for 4 hour to determine the total solids of pulp and fruit but seeds were air dried for three days. Leaf area and total soluble solid were measured by using portable leaf area meter and refractometer respectively. All collected data were statistically analyzed by analysis of variance and the treatment mean separation was done using Tukey's honestly different significance test at $\mathrm{P}<0.05$ by using Statistical Analysis System (SAS) software package.

Table 1 The chemical properties of soil and compost used in this experiment.

\begin{tabular}{l|cc}
\hline Chemical properties & $\begin{array}{c}\text { Soil at a depth } \\
\text { of } 0-10 \mathrm{~cm}\end{array}$ & Compost \\
\hline Act C.E.C & $6.3 \mathrm{meq} / 100 \mathrm{~g}$ & - \\
$\mathrm{pH}$ & 5.7 & 7.7 \\
Organic carbon & $0.3 \%$ & $25.3 \%$ \\
Electrical & $42.3 \mu \mathrm{s} \mathrm{cm}{ }^{-1}$ & - \\
conductivity & $10.0 \mu \mathrm{g} / \mathrm{g}$ & $0.87 \%$ \\
Nitrogen & $40.0 \mu \mathrm{g} / \mathrm{g}$ & $0.82 \%$ \\
Phosphorus as $\mathrm{P}_{2} \mathrm{O}_{5}$ & $0.25 \mathrm{meq} / 100 \mathrm{~g}$ & $0.79 \%$ \\
Potassium as $\mathrm{K}_{2} \mathrm{O}$ & $4.40 \mathrm{meq} / 100 \mathrm{~g}$ & $1.02 \%$ \\
Calcium & $1.27 \mathrm{meq} / 100 \mathrm{~g}$ & $0.46 \%$ \\
Magnesium & $24 \mu \mathrm{g} / \mathrm{g}$ & - \\
Sulphur as sulphate & $0.30 \mu \mathrm{g} / \mathrm{g}$ & - \\
Boron & $7.0 \mu \mathrm{g} / \mathrm{g}$ & $16 \mathrm{ppm}$ \\
Copper & $43 \mu \mathrm{g} / \mathrm{g}$ & $4358 \mathrm{ppm}$ \\
Iron & $9.0 \mu \mathrm{g} / \mathrm{g}$ & $432 \mathrm{ppm}$ \\
Manganese & $3.7 \mu \mathrm{g} / \mathrm{g}$ & $214 \mathrm{ppm}$ \\
Zinc & & \\
\hline
\end{tabular}

\section{Results and Discussion}

\section{Fruit and Pulp Weights}

Table 3 shows that there were remarkable variations $(\mathrm{P}<0.01)$ in fresh weights of pulp and single fruit which were higher (31.24 $\mathrm{g}$ and $45.49 \mathrm{~g}$ respectively) in $\mathrm{T} 6$ $\left(7.5 \mathrm{~N}+6 \mathrm{~K}_{2} \mathrm{O}+15 \mathrm{P}_{2} \mathrm{O}_{5}+2\right.$ compost) than those in the other treatments. Absolute control (T1) had significant difference $(\mathrm{P}<0.05)$ with $\mathrm{T} 6$ in these parameters but statically similar with the standard control (T2, $9 \mathrm{~N}+8 \mathrm{~K}_{2} \mathrm{O}+15 \mathrm{P}_{2} \mathrm{O}_{5}$ ) which produced $38.51 \mathrm{~g}$ fresh weight of single fruit. Pulp is the most important part in tomato fruit which is consumed and well eatable part with more preferable manner. T6 $\left(7.5 \mathrm{~N}+6 \mathrm{~K}_{2} \mathrm{O}+15 \mathrm{P}_{2} \mathrm{O}_{5}+2\right.$ compost $)$ also improved pulp dry weight and its consistency $\%$ over the control. Pulp consistency \% varied from $40.18 \%$ (T1) to $55.23 \%\left(\mathrm{~T} 8,6 \mathrm{~N}+4 \mathrm{~K}_{2} \mathrm{O}+15 \mathrm{P}_{2} \mathrm{O}_{5}+2\right.$ compost $)$ and it was not significantly different among the treatments except T1.

T6 had maximum mean value in dry weight of pulp but pulp consistency \% showed higher mean value for T8 than the other treatments. The results obtained agreed with Salam et al. (2010) who stated that application of micronutrient with NPK fertilizer exhibited higher weights of tomato pulp and fruit over NPK fertilizer alone. Further, Dube et al. (2004) reported that the pericarp thickness of fruit was increased by application of micronutrients. Combined use of micro and macro nutrients improved dry matter contents of fruit and pulp (Balasubramaniam et al., 1998). In the present study, soil application of fertilizers containing micronutrient increased pulp and fruit weights of tomato than the control. Sufficient amount of nitrogen is required at the different growing stages of tomato plants to obtain maximum fruit production. As compared to chemical fertilizers, compost normally releases nutrients slowly and also provides macro and micronutrients. Application of compost to soil increases organic matter content and provides favourable soil condition for higher crop yield (Amanullah et al., 2006).

\section{Total Soluble Solid and Seed Weight}

Total soluble solid (TSS) is the important parameter in tomato fruit. T6 and T8 were statistically similar in TSS and T6 showed higher mean value (5.73) of TSS and significantly differed from all other treatments except T8 (Table 4). This finding is conformity with De la CruzLazaro et al. (2010) who stated that in tomato, application of organic fertilizers give better quality fruit in terms of soluble solids. Mahadeen (2009) reported that combined application of both organic and chemical fertilizers had no effect on total soluble solids in Strawberry where poultry manure was applied as organic fertilizer. In present study, the TSS was increased by the application of chemical fertilizers in combination with compost. Incorporation of compost to soil increases nutrients and organic matter and also enhances the soil microbial activity. It may be the reason for increase in the TSS. Sturm et al. (2003) reported that total sugars and organic acids comprise the major part of total soluble solids. 
Table 2 Total nutrients applied to plants in each treatment.

\begin{tabular}{|c|c|c|c|c|c|c|}
\hline \multirow[b]{2}{*}{ Treatments } & \multicolumn{3}{|c|}{ Basal dressing } & \multicolumn{2}{|c|}{ Top dressing } & \multirow{2}{*}{$\begin{array}{l}\text { Total nutrients applied } \\
{\left[\mathrm{N}\left(\mathrm{g} / \mathrm{m}^{2}\right)+\mathrm{K}_{2} \mathrm{O}\left(\mathrm{g} / \mathrm{m}^{2}\right)+\right.} \\
\left.\text { Compost }\left(\mathrm{kg} / \mathrm{m}^{2}\right)\right]\end{array}$} \\
\hline & $\begin{array}{c}\mathrm{N} \\
\left(\mathrm{g} / \mathrm{m}^{2}\right)\end{array}$ & $\begin{array}{c}\mathrm{K}_{2} \mathrm{O} \\
\left(\mathrm{g} / \mathrm{m}^{2}\right)\end{array}$ & $\begin{array}{c}\text { Compost } \\
\left(\mathrm{kg} / \mathrm{m}^{2}\right)\end{array}$ & $\begin{array}{c}\mathrm{N} \\
\left(\mathrm{g} / \mathrm{m}^{2}\right)\end{array}$ & $\begin{array}{c}\mathrm{K}_{2} \mathrm{O} \\
\left(\mathrm{g} / \mathrm{m}^{2}\right)\end{array}$ & \\
\hline $\mathrm{T} 1$ & - & - & - & - & - & - \\
\hline $\mathrm{T} 2$ & 3.0 & 4 & - & 6 & 4 & $9.0 \mathrm{~N}+8 \mathrm{~K}_{2} \mathrm{O}$ \\
\hline T3 & 1.5 & 2 & 1 & 3 & 2 & $4.5 \mathrm{~N}+4 \mathrm{~K}_{2} \mathrm{O}+1$ compost \\
\hline $\mathrm{T} 4$ & 1.5 & 2 & 1 & 6 & 4 & $7.5 \mathrm{~N}+6 \mathrm{~K}_{2} \mathrm{O}+1$ compost \\
\hline T5 & 1.5 & 2 & 2 & 3 & 2 & $4.5 \mathrm{~N}+4 \mathrm{~K}_{2} \mathrm{O}+2$ compost \\
\hline T6 & 1.5 & 2 & 2 & 6 & 4 & $7.5 \mathrm{~N}+6 \mathrm{~K}_{2} \mathrm{O}+2$ compost \\
\hline $\mathrm{T} 7$ & - & - & 2 & 3 & 2 & $3.0 \mathrm{~N}+2 \mathrm{~K}_{2} \mathrm{O}+2$ compost \\
\hline $\mathrm{T} 8$ & - & - & 2 & 6 & 4 & $6.0 \mathrm{~N}+4 \mathrm{~K}_{2} \mathrm{O}+2$ compost \\
\hline
\end{tabular}

In this experiment, basal application of phosphorus $\left(\mathrm{P}_{2} \mathrm{O}_{5}\right)$ at a rate of $15 \mathrm{~g} / \mathrm{m}^{2}$ from triple superphosphate was applied to all plants except in Treatment T1. Different levels of nitrogen and potassium were applied from urea and muriate of potash respectively where half dose of nitrogen fertilizer as top dressing was applied at $3^{\text {rd }}$ week after planting and balance half was done at $6^{\text {th }}$ week. T1- absolute control, T2- standard control

Table 3 Effect of combined use of plant nutrients on fruit and pulp weights and also pulp consistency of tomato.

\begin{tabular}{l|cccc}
\hline Treatments & $\begin{array}{c}\text { Fresh weight of single } \\
\text { fruit }(\mathrm{g})\end{array}$ & $\begin{array}{c}\text { Pulp weight of single } \\
\text { fruit (fresh basis) }(\mathrm{g})\end{array}$ & $\begin{array}{c}\text { Pulp weight of single } \\
\text { fruit (dry basis) }(\mathrm{g})\end{array}$ & $\begin{array}{c}\text { Pulp consistency } \\
(\%)\end{array}$ \\
\hline T1 & $13.52^{\mathrm{e}}$ & $10.85^{\mathrm{c}}$ & $4.36^{\mathrm{c}}$ & $40.18^{\mathrm{c}}$ \\
T2 & $38.51^{\mathrm{ab}}$ & $30.54^{\mathrm{a}}$ & $15.51^{\mathrm{a}}$ & $50.78^{\mathrm{ab}}$ \\
T3 & $21.99^{\mathrm{ed}}$ & $17.60^{\mathrm{bc}}$ & $9.28^{\mathrm{b}}$ & $51.84^{\mathrm{ab}}$ \\
T4 & $34.56^{\mathrm{bc}}$ & $24.97^{\mathrm{ab}}$ & $13.23^{\mathrm{a}}$ & $52.58^{\mathrm{ab}}$ \\
T5 & $29.19^{\mathrm{bcd}}$ & $21.41^{\mathrm{abc}}$ & $11.25^{\mathrm{ab}}$ & $52.54^{\mathrm{ab}}$ \\
T6 & $45.49^{\mathrm{a}}$ & $31.24^{\mathrm{a}}$ & $15.92^{\mathrm{a}}$ & $50.96^{\mathrm{ab}}$ \\
T7 & $27.22^{\mathrm{cd}}$ & $19.86^{\mathrm{abc}}$ & $10.53^{\mathrm{ab}}$ & $53.02^{\mathrm{a}}$ \\
T8 & $37.69^{\mathrm{ab}}$ & $27.99^{\mathrm{ab}}$ & $15.66^{\mathrm{a}}$ & $55.23^{\mathrm{a}}$ \\
F test & $* *$ & $* *$ & $* *$ & $* *$ \\
CV $\%$ & 10.72 & 21.43 & 15.53 & 12.25 \\
\hline F & & $*^{2}$ & &
\end{tabular}

F test: - ** $\mathrm{P}<0.01$. Means followed by the same letter are not significantly different according to Tukey’s test at $5 \%$ significant level.

Table 4 Effect of combined use of plant nutrients on seed \%, total soluble solid, seed weight and hundred seed weight of tomato.

\begin{tabular}{|c|c|c|c|c|}
\hline Treatments & Seed $\%$ & $\begin{array}{l}\text { Total soluble solid } \\
\text { ( }{ }^{\circ} \text { brix) }\end{array}$ & $\begin{array}{l}\text { Seed weight of single fruit (air dry } \\
\text { basis) (g) }\end{array}$ & 100 seed weight $(\mathrm{g})$ \\
\hline $\mathrm{T} 1$ & $1.51^{\mathrm{b}}$ & $2.23^{\mathrm{e}}$ & $0.16^{\mathrm{d}}$ & $0.18^{\mathrm{e}}$ \\
\hline $\mathrm{T} 2$ & $1.68^{\mathrm{ab}}$ & $4.36^{\mathrm{bcd}}$ & $0.61^{\mathrm{bc}}$ & $0.32^{\mathrm{bc}}$ \\
\hline $\mathrm{T} 3$ & $1.81^{\mathrm{ab}}$ & $3.26^{\mathrm{ed}}$ & $0.41^{\mathrm{c}}$ & $0.25^{\mathrm{d}}$ \\
\hline $\mathrm{T} 4$ & $2.77^{\mathrm{ab}}$ & $4.46^{\mathrm{bc}}$ & $0.65^{\mathrm{b}}$ & $0.29^{\mathrm{cd}}$ \\
\hline T5 & $2.77^{\mathrm{ab}}$ & $4.40^{\mathrm{bc}}$ & $0.56^{\mathrm{bc}}$ & $0.29^{\mathrm{cd}}$ \\
\hline T6 & $3.31^{\mathrm{ab}}$ & $5.73^{\mathrm{a}}$ & $0.83^{\mathrm{a}}$ & $0.38^{\mathrm{a}}$ \\
\hline $\mathrm{T} 7$ & $3.55^{\mathrm{a}}$ & $3.80^{\mathrm{cd}}$ & $0.59^{\mathrm{bc}}$ & $0.26^{\mathrm{d}}$ \\
\hline $\mathrm{T} 8$ & $2.85^{\mathrm{ab}}$ & $5.20^{\mathrm{ab}}$ & $0.74^{\mathrm{ab}}$ & $0.36^{\mathrm{ab}}$ \\
\hline F test & $*$ & $* *$ & $* *$ & $* *$ \\
\hline $\mathrm{CV} \%$ & 27.93 & 7.52 & 20.45 & 6.32 \\
\hline
\end{tabular}

F test: *- $\mathrm{P}<0.05, * *_{-} \mathrm{P}<0.01$. Means followed by the same letter are not significantly different according to Tukey's test at $5 \%$ significant level.

There was significant difference $(\mathrm{P}<0.05)$ in seed \% among the treatments. In 100 seed weight, T6 and T8 were statically on par meanwhile T6 had higher mean value and significantly varied from the other treatments. Seed dry weight per fruit was recorded maximum value in T6 $(0.83 \mathrm{~g})$ followed by T8 $(0.74 \mathrm{~g})$ which was statistically similar value but T2 had $0.61 \mathrm{~g}$ seed weight. Hundred seed weight and self life of tomato are improved by the proper application of macro and micro nutrients (Bajpai et al., 2001; Davis et al., 2003). Balanced application of fertilizers plays a major role in fruit and seed production. In general, compost improves physical, chemical and biological properties of the soil. Hence, the use of chemical fertilizer with organic manure increased the seed yield.

\section{Growth Parameters}

Leaf area showed significant difference $(\mathrm{P}<0.05)$ among the treatments. It was considerably higher $\left(3164.33 \mathrm{~cm}^{2}\right)$ in T6 than that in the other treatments. In 
general, photosynthetic rate increases when leaf area increases. In performance of leaf area, T2 was statically similar with T4. T1 had lower values in all parameters indicated in Table 5 but T6 exhibited higher value with all other treatments. There were remarkable differences $(\mathrm{P}<0.01)$ in air dry weights of leaves, stem and root. T4 and T6 showed significant variation $(\mathrm{P}<0.05)$ in air dry weight of leaves meanwhile $\mathrm{T} 2$ and $\mathrm{T} 4$ exhibited similar effect. T6 had considerably higher value (54.66 g) of crop residue among the treatments. It ranged from $54.66 \mathrm{~g}$ to $14.09 \mathrm{~g}$. Incorporation of compost normally boosts the number of leaves and leaf area in tomato plants and root biomass of the tomato plants was increased by the addition of compost to the potting media of tomatoes (Lazcano et al., 2009) meanwhile compost enhances the shoot dry weight than chemical fertilizer alone in tomato plants (Ibrahim and Fadni, 2013). Gad et al. (2007) stated that farmyard manure significantly enhanced fresh and dry weights of shoots and roots of tomato.

\section{Fruit Yield Attributes}

Table 6 shows that there were highly significant differences $(\mathrm{P}<0.01)$ in fruit diameter, fruit weight and fruit yield. Fruit is the topmost important part in tomato it shows statistically no considerable variations between $\mathrm{T} 2$, T6 and T8 in total fresh and dry weights of fruits per plant. The highest fresh $(534.85 \mathrm{~g})$ and dry (289.31 g) weights of fruits per plant were recorded in T6. In fruit diameter, T2, T4 and T6 shows similar performances but T8 differed remarkably $(\mathrm{P}<0.05)$ from $\mathrm{T} 6$ in their mean values of fruit diameter. Increasing diameter consists of larger amount of total solids in tomato fruit. The average fruit diameter ranged from $2.93 \mathrm{~cm}$ (T1) to $5.00 \mathrm{~cm}$ (T6). Compost application increases the weight of fruits per plant (Durdane et al., 2011). 100\% nitrogen mineral fertilizer or $25 \%$ poultry manure $+75 \%$ nitrogen mineral fertilizer produces highest yield and fruit quality (Glala et al., 2013)

In case of fruit setting \%, all treatments except T1 had statistically similar but higher mean value was reported in T8 (38.13\%) followed by T4 (36.32\%), T5 (35.48\%) and T6 $(35.35 \%)$. Organic manure contains high amount of organic matter which improves the water holing capacity and soil microbial activity which may increase the fruit set and subsequent fruit development. Blossom drop is a common problem in tomato. It may be due to environmental factors and cultural practices. Macro and micronutrients play an important role in fruit setting and production of tomato. Therefore, the incorporation of compost to soil enhanced the fruit setting \%. In the present study, minimum and maximum fruit yield per $\mathrm{m}^{2}$ were recorded in $\mathrm{T}_{1}(0.54 \mathrm{~kg})$ and $\mathrm{T}_{6}(3.21 \mathrm{~kg})$ respectively. T6 was statistically on par with $\mathrm{T} 2(3.05 \mathrm{~kg})$ and T8 $(2.74 \mathrm{~kg})$. Ali et al. (2013) sated that application of macro and micro nutrients increases the fruit weight and fruit yield.

Table 5 Effect of combined use of plant nutrients on leaf area, dry weights of plant parts and crop residue of tomato

\begin{tabular}{|c|c|c|c|c|c|}
\hline Treatments & $\begin{array}{l}\text { Leaf area } \\
\left(\mathrm{cm}^{2}\right)\end{array}$ & $\begin{array}{c}\text { Air dry weight of } \\
\text { leaves }(g)\end{array}$ & $\begin{array}{c}\text { Air dry weight of } \\
\text { stem }(\mathrm{g})\end{array}$ & $\begin{array}{c}\text { Air dry weight of } \\
\text { root }(\mathrm{g})\end{array}$ & $\begin{array}{c}\text { Crop residue } \\
(\mathrm{g})\end{array}$ \\
\hline $\mathrm{T} 1$ & $868.33^{\mathrm{e}}$ & $6.63^{\mathrm{e}}$ & $5.83^{\mathrm{f}}$ & $1.64^{\mathrm{g}}$ & $14.09 \mathrm{f}$ \\
\hline $\mathrm{T} 2$ & $2286.33^{c}$ & $17.98^{\mathrm{c}}$ & $20.08^{\mathrm{ab}}$ & $5.82^{\mathrm{cd}}$ & $43.88^{c}$ \\
\hline $\mathrm{T} 3$ & $1814.00^{\mathrm{d}}$ & $14.14^{\mathrm{d}}$ & $13.26^{\mathrm{de}}$ & $3.63^{f}$ & $31.03 \mathrm{e}$ \\
\hline $\mathrm{T} 4$ & $2402.67^{\mathrm{c}}$ & $20.35^{\mathrm{bc}}$ & $18.33^{\mathrm{c}}$ & $5.94^{\mathrm{cb}}$ & $44.62^{c}$ \\
\hline T5 & $1961.67^{\mathrm{d}}$ & $18.05^{\mathrm{c}}$ & $17.95^{\mathrm{cd}}$ & $5.56^{\mathrm{de}}$ & $41.56 \mathrm{~d}$ \\
\hline T6 & $3164.33^{\mathrm{a}}$ & $25.34^{\mathrm{a}}$ & $22.14^{\mathrm{a}}$ & $7.18^{\mathrm{a}}$ & $54.66^{\mathrm{a}}$ \\
\hline $\mathrm{T} 7$ & $2145.67^{d}$ & $19.91^{\mathrm{c}}$ & $16.62^{\mathrm{d}}$ & $5.43^{\mathrm{e}}$ & $41.96^{\mathrm{d}}$ \\
\hline $\mathrm{T} 8$ & $2769.67^{b}$ & $23.66^{\mathrm{ab}}$ & $21.42^{\mathrm{ab}}$ & $6.82^{b}$ & $51.90^{\mathrm{b}}$ \\
\hline$F$ test & $* *$ & $* *$ & $* *$ & $* *$ & $* *$ \\
\hline $\mathrm{CV} \%$ & 3.56 & 7.4 & 7.74 & 6.28 & 4.54 \\
\hline
\end{tabular}

F test: $*_{-} \mathrm{P}<0.01$. Means followed by the same letter are not significantly different according to Tukey's test at $5 \%$ significant level.

Table 6 Effect of combined use of plant nutrients on fresh and dry weights of fruits per plant and fruit yield of tomato.

\begin{tabular}{|c|c|c|c|c|c|}
\hline Treatments & $\begin{array}{c}\text { Fruit setting } \\
\%\end{array}$ & $\begin{array}{c}\text { Fruit diameter } \\
(\mathrm{cm})\end{array}$ & $\begin{array}{l}\text { Fresh weight of } \\
\text { fruits per plant }(\mathrm{g})\end{array}$ & $\begin{array}{c}\text { Dry weight of fruits } \\
\text { per plant }(\mathrm{g})\end{array}$ & $\begin{array}{c}\text { Fruit yield } \\
\left(\mathrm{kg} / \mathrm{m}^{2}\right)\end{array}$ \\
\hline $\mathrm{T} 1$ & $13.91^{b}$ & $2.93^{\mathrm{e}}$ & $90.26^{\mathrm{d}}$ & $47.04^{\mathrm{d}}$ & $0.54^{\mathrm{e}}$ \\
\hline $\mathrm{T} 2$ & $26.44^{\mathrm{ab}}$ & $4.83^{\mathrm{ab}}$ & $508.18^{\mathrm{a}}$ & $278.43^{\mathrm{a}}$ & $3.05^{\mathrm{a}}$ \\
\hline $\mathrm{T} 3$ & $24.90^{\mathrm{ab}}$ & $4.20^{\mathrm{cd}}$ & $246.58 \mathrm{c}$ & $138.44 \mathrm{c}$ & $1.48^{\mathrm{dc}}$ \\
\hline $\mathrm{T} 4$ & $36.32^{\mathrm{a}}$ & $4.73^{\mathrm{abc}}$ & $414.46 b$ & $227.44 b$ & $2.49^{b}$ \\
\hline T5 & $35.48^{\mathrm{a}}$ & $3.86^{\mathrm{d}}$ & $378.15^{b}$ & $212.37^{b}$ & $2.39^{b c}$ \\
\hline T6 & $35.35^{\mathrm{a}}$ & $5.00^{\mathrm{a}}$ & $534.85^{\mathrm{a}}$ & $289.31^{\mathrm{a}}$ & $3.21^{\mathrm{a}}$ \\
\hline $\mathrm{T} 7$ & $32.74^{\mathrm{a}}$ & $4.03^{\mathrm{d}}$ & $335.15^{b c}$ & $176.18^{b c}$ & $2.01^{\mathrm{c}}$ \\
\hline T8 & $38.13^{\mathrm{a}}$ & $4.36^{\mathrm{bcd}}$ & $456.05 \mathrm{ab}$ & $249.33^{\mathrm{ab}}$ & $2.74^{\mathrm{ab}}$ \\
\hline F test & $*$ & $* *$ & $* *$ & $* *$ & $* *$ \\
\hline $\mathrm{CV} \%$ & 21.73 & 4.85 & 11.66 & 12.37 & 4.85 \\
\hline
\end{tabular}




\section{Conclusion}

This study revealed that there were highly significant differences $(\mathrm{P}<0.01)$ in most of the growth and yield parameters of tomato. $\mathrm{T} 2\left(9.0 \mathrm{~g} \mathrm{~N}+8 \mathrm{~g} \mathrm{~K}_{2} \mathrm{O}+15 \mathrm{~g} \mathrm{P}_{2} \mathrm{O}_{5}\right.$ per $\left.\mathrm{m}^{2}\right)$, T6 $\left(7.5 \mathrm{~g} \mathrm{~N}+6 \mathrm{~g} \mathrm{~K}_{2} \mathrm{O}+15 \mathrm{~g} \mathrm{P}_{2} \mathrm{O}_{5}+2 \mathrm{~kg}\right.$ compost per $\left.\mathrm{m}^{2}\right)$ and $\mathrm{T} 8\left(6.0 \mathrm{~g} \mathrm{~N}+4 \mathrm{~g} \mathrm{~K}_{2} \mathrm{O}+15 \mathrm{~g} \mathrm{P}_{2} \mathrm{O}_{5}+\right.$ $2 \mathrm{~kg}$ compost per $\mathrm{m}^{2}$ ) showed similar performances in fruit weight, pulp weight and fruit yield. But T6 showed better performance in most of the parameters and had the higher mean values than the other treatments and also basal application of recommended doses of NK chemical fertilizers could be reduced by $50 \%$ in $\mathrm{T} 6$ treatment as compared with standard control (T2) ie chemical fertilizers alone. Hence, application of chemical fertilizers $\left(7.5 \mathrm{~g} \mathrm{~N}+6 \mathrm{~g} \mathrm{~K}_{2} \mathrm{O}+15 \mathrm{~g} \mathrm{P}_{2} \mathrm{O}_{5}\right.$ per $\left.\mathrm{m}^{2}\right)$ with compost $(2$ $\mathrm{kg}$ per $\mathrm{m}^{2}$ ) could be done to obtain higher fruit yield over chemical fertilizers alone in tomato cultivation.

\section{References}

Aisha AH, Rizk FA, Shaheen AM, Abdel-Mouty MM. 2007. Onion plant growth, bulbs yield and its physical and chemical properties as affected by organic and natural fertilization. Res. J. Agric. Biol. Sci., 3:5, 380-388.

Ali S, Javed HU, Rehman RNU, Sabir IA, Naeem MS, Siddiqui MZ, Saeed DA, Nawaz MA. 2013. Foliar application of some macro and micro nutrients improves tomato growth, flowering and yield. Int. J. Biosci., 3:10, 280-287.

Amanullah MM, Vaiyapuri K. and Alagesan A. 2006. Effect of intercropping and organic manures on the yield and biological efficiency of cassava intercropping system (Manihot esculenta Crantz). Res. J. Agric. Biol. Sci., 2:5, 201-208.

Awad AM, Tartoura EA, Elfouly HM, Fattah AI. 2002. Response of potato growth, yield and quality to farmyard manure sulphur and gypsum levels application. $2^{\text {nd }}$ Int. Conf. Hort. Sci., ElSheikh, Tanta University, Egypt, pp: 24-39.

Bajpai S, Chouhan SVS, Bajpai S. 2001. Effect of zinc, boron and manganese on yield of okra (Abelmoschus esculentum L.). Indian J. Agric. Sci., 71:5, 332-333.

Balasubramaniam P, Mani AK, Duraisamy P, Kandaswami M. 1998. Effect of organic and inorganic nutrients on the yield and uptake of tomato. South Indian Hort., 46:3-6, 143-147.

Davis TM, Sanders DC, Nelson PV, Lengnick L, Sperry WJ. 2003. Boron improves growth, yield, quality and nutrient content of tomato. J. Am. Soc. Hort. Sci., 128:3, 441-446.
De la Cruz-Lazaro E, Osorio-Osorio R, Martinez-Moreno E, Del Rio AJL, Gomez-Vazquez A, Sanchez-Hernandez R. 2010. Use of composts and vermicomposts for organic production of tomato in greenhouses. Interciencia 35: 363-368.

Dube BK, Pratima S, Chatterjee C. 2004. Effects of boron and zinc on the yield and quality of tomato. Indian J. Hort., 61:1, 48-52.

Durdane Y, Naif G, Yusuf Y, Mine A, Perihan C. 2011. Effect of different organic fertilizers on yield and fruit quality of indeterminate tomato (Lycopersicon esculentum L.). Sci. Res. Essays, 6:17, 3623-3628.

Gad AA, Ghamriny EA, Bardisi A, Shazly AA. 2007. Effect of farmyard manure and mineral nitrogen sources and rates on dry weight, photosynthetic pigments and yield of tomato grown in sandy soil. Zagazig J. Agric. Res., 34:5, 845- 869.

Glala AAA, Neama M, Marzouk MSS, Al-Bassyuni, Nagwa, Hassan M.K. 2013. Influence of Organic Nitrogen Fertilizers Replacement Rates Associated with Azosprillum spp, Enrichment on Tomato. J. Appl. Sci. Res., 9:3, 1952-1959.

Ibrahim KHM, Fadni OAS. 2013. Effect of Organic Fertilizers Application on Growth, Yield and Quality of Tomatoes in North Kordofan (sandy soil) western Sudan. Greener J. Agric. Sci., 3:4, 299-304.

Kumar P. 2003. Effect of integrated nutrient management on sustainable cabbage and tomato production. Ph.D. Thesis, Department of Vegetable Crops, Dr. YS Parmar University of Horticulture and Forestry, Nauni, Solan. Pp: 282.

Lazcano C, Arnold J, Tato A, Zaller JG, Domínguez J. 2009. Compost and vermicompost as nursery pot components: effects on tomato plant growth and morphology. Spanish J. Agric. Res., 7:4, 944-951.

Mahadeen AY. 2009. Influence of organic and chemical fertilization on fruit yield and quality of plastic-house grown strawberry. Jordan J. Agric. Sci. 5:2,167-176.

Mehdizadeh M, Darbandi EI, Naseri-Rad H, Tobeh A. 2013. Growth and yield of tomato (Lycopersicon esculentum Mill.) as influenced by different organic fertilizers. Int. J. Agron. Plant Prod., 4:4, 734-738.

Nanwai RK, Sharma BD, Taneja KD. 1998. Role of organic and inorganic fertilizers for maximizing wheat (Triticum) aestivum yield in sandy loam soils. Crop res. Hisar, 16:2, 159-161.

Natarajan K. 2007. Panchagavya for plant. Proc. Nation. Conf. Glory Gomatha, S. V. Veterinary University, Tirupati, pp: 7275.

Salam MA, Siddique MA, Rahim MA, Rahman MA, Saha MG. 2010. Quality of Tomato (Lycopersicon esculentum Mill.) as Influenced by Boron and Zinc under Different Levels of NPK Fertilizers. Bangladesh J. Agric. Res., 35:3, 475-488.

Sreenivasa MN, Nagaraj MN, Bhat SN. 2010. Beejamruth: A source for beneficial bacteria. Karnataka J. Agric. Sci., 17:3, 72-77.

Sturm K, Koron D and Stampar F. 2003. The composition of fruit of different strawberry varieties depending on maturity stage. Food Chem., 83: 417-422. 